\section{BEGELEIDING VAN ADHD BIJ VOLWASSENEN}

Sandra J.J. Kooij. ADHD bij volwassenen. Diagnostiek en behandeling. Amsterdam: Pearson Benelux BV, 2017. 324 pagina's. ISBN 9789043035934. Prijs € 44,95.

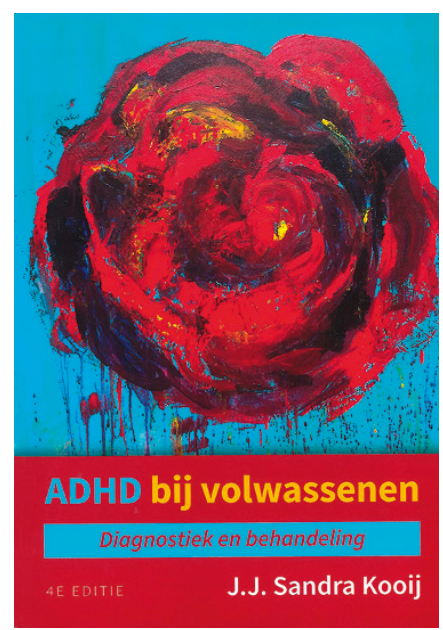

Van alle volwassenen in Nederland heeft 3\% ADHD. Dit boek biedt een overzicht van de huidige stand van de wetenschap, en van de diagnostiek en behandeling. Het richt zich zowel op de beginnende als op de ervaren hulpverlener.

Sandra Kooij is psychiater en onderzoeker op het gebied van ADHD bij volwassenen. Zij beschouwt ADHD als een chronische aandoening, hetgeen langdurige behandeling en begeleiding impliceert, net als diabetes mellitus. ADHD bij volwassenen bevat zes hoofdstukken. Hoofdstuk 1 beschrijft de geschiedenis van ADHD. Hoofdstuk 2 behandelt diagnostiek en comorbiditeit. Hoofdstuk 3 bespreekt de diagnostische instrumenten (toegevoegd als bijlagen). Hoofdstuk 4 gaat over de behandeling (psycho-educatie, coaching en medicatie). Hoofdstuk 5 bespreekt coaching en cognitieve gedragstherapie, relevant voor de pohggz. Hoofdstuk 6 ten slotte beschrijft de opzet en organisatie van een polikliniek en levenslooppoli ADHD.

Door de heldere inhoud en de handige indeling is het makkelijk zoeken naar een specifiek onderwerp. Hierdoor heeft het boek zowel de gemiddelde als zeer geïnteresseerde huisarts veel te bieden. Er zijn echter ook kritische noten. Door ADHD te bestempelen als een chronische aandoening wordt de aandoening onnodig gemedicaliseerd. Het verlagen van het afkappunt zal tot meer (over)diagnoses leiden. De ervaring van de auteur in de tweedelijns psychiatrie heeft de inhoud duidelijk beïnvloed. Er staan ook veel aannames in waarvan oorzaak en gevolg niet altijd helder worden onderbouwd. Verder mis ik een hoofdstuk over de samenwerking met de huisarts en aansluiting bij de NHG-Standaard ADHD bij kinderen. Voor de huisarts geeft de standaard voldoende informatie om onderscheid te maken tussen ADHD als stoornis en het hebben van klachten en daarop het te volgen beleid. Dit boek biedt veel en nuttige informatie voor de huisarts en poh-ggz, maar daarbij is een kritische en nuancerende blik nodig.

Ron Glotzbach

\section{DWANGSTOORNISSEN IN DE PRAKTIJK}

Menno Oosterhoff. Vals Alarm. Hilversum: uitgeverij Lucht BV, 2017. 367 pagina's. ISBN 978-94-9172-968-3. Prijs paperback € 22,50 of ebook $€ 9,99$.

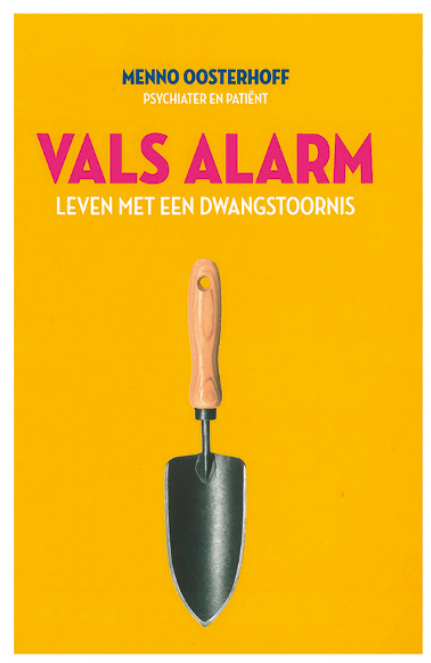

Psychiater Menno Oosterhoff is gespecialiseerd in dwangstoornissen. Hij is ook ervaringsdeskundige. In dit boek beschrijft hij op creatieve wijze de impact van dwangstoornissen op het persoonlijke, sociale en maatschappelijke leven en maakt zijn unieke kennis voor iedereen toegankelijk. Oosterhoff maakt het graduele disfunctioneren zichtbaar aan de hand van alledaagse, voor iedereen herkenbare voorbeelden tot en met extreme obsessies en compulsies.

Een dwangstoornis is voor de patiënt een plaag en doet zich voor in een geleidelijke schaal van lichte controledwang tot hardnekkige dwanggedachten (obsessies) en dwanghandelingen (compulsies). Zo'n 1 tot $2 \%$ van de bevolking lijdt eraan. Nog niet zo lang geleden dachten artsen dat dwang voortkwam uit angst, maar zij hebben dit idee losgelaten. Patiënten ervaren een obsessieve onrust als iets 'niet helemaal goed voelt' (just-not-right-feeling) of als iets onvolledig of onaf is (feeling of incompleteness). Deze onrust leidt tot het uitvoeren van dwanghandelingen, maar hierdoor nemen de problemen juist toe. In de behandeling gaat het erom de onrust te leren verdragen. Onvolkomenheden horen nu eenmaal bij het leven. Mensen met dwang zijn gewend rekening te houden met het ergste en zoeken absolute zekerheden. Maar hoe zeker is zeker? Via algemene wijsheden oftewel 'dooddoeners' corrigeert Oosterhoff zijn patiënten en leert hen dat 'goed genoeg' effectiever is dan nastreven van perfectie. Hij is een meester in het eenvoudig uitleggen van de werkingsmechanismen bij dwang. Dat doet hij met metaforen en leuke anekdotes. Huisartsen kunnen hiervan leren. Drukke huisartsen raad ik aan om de hoofdstukken 1, 2, 7 en 8 te lezen. Mooi is ook hoofdstuk 13, waarin Menno's vrouw vertelt over de betekenis van een dwangstoornis voor de gezinsleden.

Marian Oud

WAARDERING:

WAARDERING: 